\title{
BARKER (Eileen), WARBURG (Margit), eds, New Religions and New Religiosity
}

Aarhus, Aarhus University Press, 1998, 309 p. (index)

Nathalie Luca

\section{OpenEdition}

\section{Journals}

Édition électronique

URL : http://journals.openedition.org/assr/20841

DOI : $10.4000 /$ assr. 20841

ISSN : $1777-5825$

Éditeur

Éditions de l'EHESS

Édition imprimée

Date de publication : 1 juin 2001

Pagination : 125

ISBN : 2-222-96704-X

ISSN : 0335-5985

\section{Référence électronique}

Nathalie Luca, «BARKER (Eileen), WARBURG (Margit), eds, New Religions and New Religiosity»,

Archives de sciences sociales des religions [En ligne], 114 | avril-juin 2001, document 114.51, mis en ligne le 19 août 2009, consulté le 21 septembre 2020. URL : http://journals.openedition.org/assr/ 20841 ; DOI : https://doi.org/10.4000/assr.20841

Ce document a été généré automatiquement le 21 septembre 2020.

(c) Archives de sciences sociales des religions 


\section{BARKER (Eileen), WARBURG (Margit), eds, New Religions and New Religiosity \\ Aarhus, Aarhus University Press, 1998, 309 p. (index)}

Nathalie Luca

\section{RÉFÉRENCE}

BARKER (Eileen), WARBURG (Margit), eds, New Religions and New Religiosity, Aarhus, Aarhus University Press, 1998, 309 p. (index)

1 Résultat de la conférence de Rennord'94 tenue à Copenhague en août 1994, cet ouvrage est à conseiller aux étudiants qui s'intéressent aux Nouveaux Mouvements Religieux. Il traite du contexte d'apparition des N.M.R., explique le choix de cette expression, présente quelques essais théoriques à travers Danièle Hervieu-Léger, Gordon Melton ou Massimo Introvigne, notamment. Il offre également des études de cas, faites dans différents pays et contextes culturels (les pays de l'Est, l'Inde, les U.S.A., l'Europe), sur des groupes très hétérogènes (allant des charismatiques catholiques à la Scientologie, en passant par le New-Age). Enfin, il s'intéresse aux réactions sociales que suscitent ces groupes disparates dans plusieurs pays (Grande-Bretagne, Italie, U.S.A., Allemagne, Danemark). 